\title{
Szervezeti integritás a büntetőjogi felelősségre vonás megelőzése érdekében - Integritáselmélet kriminálprofilaktikus megközelítésben
}

\author{
Integrity in Organization to Prevent Criminal Liability - \\ Integrity Theory in Criminal Prophylaxis Approach
}

\begin{abstract}
Absztrakt
A bünmegelőzés elsődlegesen állami feladat. Vannak azonban olyan speciális területek, ahol az állam nem képes önállóan hatékonyan ellátni ezt a feladatot, a felderítési nehézség pedig az adott büncselekmények fokozott látenciáját eredményezi. A csekély felderítési eredményesség a deliktumok elkövetésének folytatására motivál akkor is, ha az adott magatartás elkövetése esetére a jogalkotó magas szankciókat helyez kilátásba. A krudélis mértékü szankciók csak akkor jelentenének visszatartó erőt, ha a büncselekmény elkövetője a cselekmény magas felderítési potenciálja miatt a feltétlen felelösségre vonástól alappal tarthat. Ennek hiányában azonban a szankciónövelés nem optimális eszköze a látencia csökkentésének, így a bünmegelözésnek sem. Ilyen felderítési kihívást jelentő terület a szervezeten belüli bünelkövetés is, hiszen a szervezet zárt, hierarchikus felépítése miatt alkalmas arra, hogy az annak keretei között kifejtésre kerülő jogellenes magatartásokat a külvilág, és így a bünüldöző hatóságok előtt is leplezze. Elemi állami érdek ezért a szervezetek ösztönzése arra, hogy a kereteik között történő visszaélések megvalósulását megakadályozzák akkor is, ha azok egyébként a szervezet érdekeit szolgálják. Az integritásszemlélet a szervezet, illetve az annak részét képező egyének morálisan tiszta müködését segíti elö, ezáltal alkalmas eszközrendszer arra is, hogy a szervezeten belül elkövetett, tipikusan látens gazdasági, valamint korrupciós büncselekményeket megakadályozza. A tanulmány a szervezeti integritással foglalkozik kriminológiai, szükebben bünmegelőzési megközelítésben. Az integritás jelentésének kriminológiai szempontból is használható megfogalmazását követően foglalkozik az
\end{abstract}


integritás és a compliance viszonyrendszerével, majd azzal a kérdéssel, hogy a szervezet milyen motivációs tényezők miatt válik egyáltalán veszélyforrássá, kriminogén közeggé, valamint ezeket a tényezőket miképpen lehet kiküszöbölni. A tanulmány utolsó fejezete az integritásmenedzsment eszközök bünmegelözési relevanciájával foglalkozik.

Kulcsszavak: integritás, bünmegelőzés, compliance, szervezet, morál

\begin{abstract}
Crime prevention is an obligation of a state. However, there are special areas where the state is unable to perform this obligation effectively on its own, therefore the difficulty of detection results in increased latency for specific crimes. Low detection efficiency motivates the continuation of commit these crimes, even if the legislator envisages high sanctions for the commission of the given conduct. Crudely sanctions would only act as a deterrent if the perpetrator of the crime could reasonably fear unconditional prosecution because of the high detection potential of the act. In the absence of this, increasing sanctions is not an optimal means of reducing latency, and thus of crime prevention. Such an area of detection challenge is also crime within the organization, as due to the closed, hierarchical structure of the organization, it is suitable to reveal illegal behaviors committed within its framework to the outside world, and thus to law enforcement authorities. It is therefore in the fundamental interest of the state to encourage organizations to prevent abuses within their framework, even if they otherwise serve the interests of the organization. The integrity approach promotes the morally clean operation of the organization and the individuals that are part of it, thus it is also a suitable system of tools to prevent the typically latent economic and corruption crimes committed within the organization. The study deals with organizational integrity in a criminological, more narrowly, crime prevention approach. After formulating the meaning of integrity from a criminological point of view, it deals with the relationship between integrity and compliance, and then with the question of what motivating factors make the organization to a source of danger at all, to a criminogenic area, and how to eliminate these factors. The final chapter of the study addresses the crime prevention relevance of integrity management tools.
\end{abstract}

Keywords: integrity, crime prevention, compliance, organization, moral 


\section{Bevezetés}

Az állami kontrollfunkció részeleme a kriminálprofilaxis, azaz a bünmegelőzés. Abban azonban nemcsak az állam vesz részt, hanem a társadalom egyes tagjai, valamint társadalmi csoportok is, tekintettel egyrészt arra, hogy a bünmegelözés általánosságban egyéni érdek is, valamint az állam nem képes arra, hogy mindenhol jelen legyen, illetve mindenhol kellő hatékonysággal beavatkozzon (Inzelt \& Bezsenyi, 2021). Az egyik terület, ahol bünmegelőzési szempontból az állam a legnehezebb feladatainak egyikével néz szembe, az a szervezeten belül, tipikusan a szervezet érdekében elkövetett büncselekmények. A szervezetek, vállalkozások legáltalánosabb értelemben olyan zárt, hierarchikusan felépített entitások, amelyek szabályszerü müködéséhez fokozott állami, egyéni, valamint szervezeti érdek füződik. A visszaélésektől mentes müködés azonban nem evidencia. Ahhoz, hogy egy szervezet tisztán, szabályszerüen, visszaélésektől mentesen, etikusan, morális elveknek megfelelően müködjön, a szervezet vezetőjének olyan kontrollrendszert kell kiépítenie, amellyel a szervezet integritás alapú müködését garantálni képes. E speciális kötelezettség létének az az alapvető indoka, hogy a szervezet individuumok összessége, ugyanakkor a külvilág felé önálló egységként jelenik meg. A szervezetet ezért kollektív szereplönek kell tekinteni, ami azt jelenti, hogy tagjainak cselekvései a szervezet cselekvéseként jelennek meg, a külvilág az egyes tagok szervezeti magatartásait ekképpen érzékeli (Schöttl, 2017). Ezért akkor, amikor szervezeti integritásról beszélünk, tulajdonképpen a szervezet tagjai, dolgozói magatartásának összességéről van szó. A szervezet morális müködése a tagok etikus magatartásán alapszik tehát azáltal, hogy a szervezet az etikus magatartástanúsítás keretrendszerét kiépíti. Amennyiben a szervezeten belül olyan magatartás kifejtésére kerül sor, amely sérti annak integritását, és amely adott esetben valamely jogági felelősségi forma keretei közé illeszkedik, úgy a szervezet mint egység felelősségének megállapítása indokolt. Amennyiben ugyanis a szervezet individuumokat egyesítő, saját vezérelvek és morális normák szerint müködő entitás, úgy logikus, hogy a szervezeten belüli jogellenes magatartásokért maga a szervezet (is) felelősséget viseljen. A szervezeti felelősség léte kívánalmának alapja Sántha Ferenc megfogalmazása szerint az, , hogy a szervezet müködése törvénysértö, így a felelösség alapja a szervezet társadalomra veszélyessége, mivel ennek megnyilvánulása, mintegy tünete a keretei között elkövetett büncselekmény" (Sántha, 2002). Minden szervezet elemi érdeke az, hogy megelözze olyan magatartásoknak a keretei között történő megvalósítását, amely individuális magatartások járulékosan a szervezet szankcionálását vonják maguk után. Az ebben az értelemben vett felelősségelkerülés érdekében a szervezet 
minden olyan intézkedést érdekelt megtenni, amely elősegíti, garantálja a törvényes müködését. A potenciális büntetőjogi jogkövetkezmények mellett a reputációvesztés is jelentős károkat tud okozni a szervezet müködésében. Minél magasabb színvonalú az integritása egy vállalkozásnak, annál rezisztensebb a keretei között történő bűnelkövetéssel szemben, ezáltal azok káros következményeinek esélye is redukálódik (Pulay, 2014).

A tanulmány célja a szervezeti integritás, illetve az integritási eszközök kriminálpreventív hatásának elemzése, illetve annak a kérdésnek a megválaszolása, hogy a szervezeti integritáskontroll eszközei optimális bünmegelőzési instrumentumok-e. Mindenekelőtt meghatározásra kerül az integritásnak egy olyan általános fogalma, amely a későbbi elemzés során alapul szolgál a profilaktikai megközelítés szempontjából. Nem elegendő azonban az integritás fogalmát egyszerüen megadni, indokolt azt elhelyezni egy tágabb rendszerben, a belső szervezeti kontrollmechanizmusok rendszerében. Ezért a tanulmány foglalkozik az integritás szervezeti kultúrában elfoglalt helyének és funkciójának megállapításával, valamint a compliance, különösen a criminal compliance fogalmához való viszonyával. A bünmegelözés előfeltétele a kriminogén tényezők felismerése, detektálása, a bünelkövetéssel kapcsolatos magatartások megvalósítása tekintetében törvényszerüségek meghatározása. Ezért a tanulmány foglalkozik azzal a kérdéssel, hogy mely tényezők segítik elő a szervezeti bünözést, és miért tekinthető a szervezet alapvetően kriminogén veszélyforrásnak. A bűnmegelőzést célzó krimináletiológiai kérdések közé tartozik a bünelkövetésre ösztönző potenciális motivációk felismerése, hiszen a visszaélésszerủ magatartások elkövetésére motiváló tényezők eliminálása profilaktikai szempontból elsődleges cél. Végül az alapfogalmak, azok viszonyrendszere, valamint a kriminogén környezet, és a szervezeti bünelkövetésre ösztönző tényezők feltárását követően kerül sor az integritásmenedzsment bünmegelőzési szempontú vizsgálatára.

\section{Az integritás jelentése, rendszerbeli helye és bünmegelözési jelentősége}

A szervezeti integritás jelentésének vizsgálata során a szervezeti müködést tágabb megvilágításba kell helyezni. A szervezetek társadalmi-gazdasági makrokörnyezetben léteznek, ezért az általános morális értékrendszer, illetve azok potenciális normatív leképeződése alapvetően meghatározza valamely szervezet müködési keretrendszerét. A vállalkozás integritás alapú müködését, de facto az abban tevékenységet végző individuumok szervezetkonform magatartása idézi elő, ily módon az integritási kérdések mikroszinten történő vizsgálata 
elemi követelmény. Az említett két szint között helyezkedik el maga a szervezet, amely a külvilág felé mint egység jelenik meg (Schöttl, 2017). Emiatt mezoszinten, tehát a szervezet szintjén elemi érdek az integritás megteremtése a mindenkori társadalmi-gazdasági morális elveknek, jogi normáknak való megfelelés garantálásával, a szervezetben tevékenységet végző individuumok magatartásának etikai, valamint normatív eszközökkel történő determinálása útján. Ahogyan a továbbiakban látni fogjuk, az integritás fogalmi szinten elsősorban a mezoszintre koncentrál, integritásmenedzsment szempontjából viszont a mikroszintre irányuló fókusz dominál.

\section{Az integritás jelentése és profilaktikai relevanciája}

A szervezeti integritás fogalma először a közszféra szervezeti jogában jelent meg, definíció szintjén a mai napig csak közigazgatási jogi normában találkozunk a terminus technikussal (Boros, 2019). Az államigazgatási szervek integritásirányítási rendszeréről és az érdekérvényesítők fogadásának rendjéről szóló 50/2013. (II. 25.) Korm. rendelet (továbbiakban: Intr.) 2. § a) pontja szerint az integritás ,, az államigazgatási szerv szabályszerü, a hivatali szervezet vezetöje és az irányitó szerv által meghatározott célkitüzéseknek, értékeknek és elveknek megfelelö müködése”. Integritás kockázat alatt pedig „az államigazgatási szerv célkitüzéseit, értékeit, elveit sértö vagy veszélyeztetö visszaélés, szabálytalanság vagy egyéb esemény lehetöségét [Intr. 2. §a) pont és b) pont] értjük" (Klotz, 2017). A költségvetési szervek belső kontrollrendszeréről és belső ellenőrzéséröl szóló 370/2011. (XII. 31.) Korm. rendelet (továbbiakban: Bkr.) 2. § u) pontja értelmében szervezeti integritást sértő cselekmény „minden olyan esemény, amely a szervezetre vonatkozó szabályoktól, valamint a jogszabályi keretek között a költségvetési szerv vezetöje és az irányitó szerv által meghatározott szervezeti célkitüzéseknek, értékeknek és elveknek megfelelö müködéstöl eltér".

A Bkr. hatálya a kormány irányítása vagy felügyelete alatt álló államigazgatási szervekre és azok munkatársaira terjed ki, a rendvédelmi szervek és a Katonai Nemzetbiztonsági Szolgálat kivételével (Dargay, 2015). A rendvédelmi szervek vonatkozásában fontos megjegyezni azonban, hogy attól függetlenül, hogy azokra a Bkr. hatálya nem terjed ki, az integritási szemlélet régtől fogva nem idegen e szervektől, ahogyan Dargay megállapítja, különösen a korrupciós kockázatok kivédése érdekében léteznek 1997 óta speciális szervezeti mechanizmusok (Dargay, 2015). A rendvédelmi szervek, valamint 2021. január 1-jétől az egészségügyi szolgáltatók szempontjából kiemelést érdemel a megbízhatósági 
vizsgálat mint bünmegelőző integritási eszköz alkalmazása. [Az egészségügyi szolgáltatók vonatkozásában kifejthető korrupciós magatartások kriminalizálásával párhuzamosan a jogalkotó lehetőséget teremtett e korrupciós magatartások eredményes feltárása, illetve megelözése érdekében a megbízhatósági vizsgálat alkalmazására. A Rendőrségről szóló 1994. évi XXXIV. törvény 7. § (1) bekezdés b) pontját a Kormányzati Személyügyi Döntéstámogató Rendszerről szóló 2020. évi CLXII. törvény módosította, ezáltal megteremtette a hálapénzzel kapcsolatos magatartások ilyen módon történő felderítésének lehetőségét. A rendvédelmi szervek integritásával részletesen foglalkozik Klotz Péter (Klotz, 2017).] Jóllehet a megbízhatósági vizsgálat elsősorban bünfelderítési, illetve visszaélésfelderítési eszköznek tünik, szervezeti bünmegelőzés szempontból is különös jelentőséggel bír, célja ugyanis elsősorban - Klotz Péter megfogalmazása szerint - „a szervezet egészére káros, korrumpálódott egyének, klasszikus hasonlattal élve a »romlott almák « felderitése és eltávolitása" (Klotz, 2017). Ilyen módon a hatékony bünfelderítés generálpreventív hatással bír (Molnár, 2021).

Pulay Gyula megfogalmazása szerint szervezetirányítási szempontból, általános értelemben az integritás azt jelenti, ,, hogy a szervezetnek van egy pozitiv, a társadalmi elvárasokkal összhangban álló, szilárd értékrendje és ezen értékek mentén müködik" (Pulay, 2014). Ha az államigazgatási szervek vonatkozásában meghatározott normatív fogalmat felhasználva egy általános, valamennyi szervezetre alkalmazható, területspecifikáció nélküli integritásfogalmat szeretnénk megadni, úgy azt mondhatjuk, hogy a szervezeti integritás a szervezetre vonatkozó normáknak, valamint a szervezet részére vagy általa meghatározott értékeknek és elveknek megfelelő működés, illetve az erre való törekvés. Ez utóbbi fogalmi kitétel azért fontos, mert a szervezeten belül az individuális tényező teljes mértékben nem küszöbölhető ki. A szervezeti integritást sértő magatartás megelözésére megtett valamennyi intézkedés ellenére is bekövetkezhet ilyen cselekmény, ugyanakkor ez nem feltétlen jelenti azt, hogy a szervezet nem követett el mindent annak érdekében, hogy az integritás alapú müködést garantálja. Egyetértek tehát Pulay álláspontjával, miszerint ,, az integritás nem általában jelenti egy szervezet szabályos müködését, hanem csak azt, hogy a szervezet a helytelen dolgozói magatartás miatti kockázatokat csökkentette le nagyon nagy mértékben" (Pulay, 2014).

A közszférára sokkal jellemzőbb az úgynevezett szabálydetermináltság, mint a magánszféra szervezeti kultúrájára, így nem ritkán normák határoznak meg olyan magatartási elvárásokat is, amelyek a vállalatok, gazdálkodó szervezetek vonatkozásában nem vagy ritkán kerülnek normatív szinten rögzítésre. Emiatt egy mélyebb elemzés esetén integritási szempontból is indokolt a közszféra, valamint a magánszféra szervezeti jogát külön tárgyalni. E tanulmány azonban 
elsősorban nem a szabálydetermináltságra koncentrál, hanem az integritás mint eszközrendszer, mint szemléletmód általános bünmegelőzési relevanciájára. Tekintettel arra, hogy a büntetöjogi tilalmazottság mindig törvényben van rögzítve, úgy e tekintetben a normadetermináltság mindkét szféra szervezeti szemléletmódjára jellemző kell, hogy legyen, így a tanulmány fókuszának szempontjából szignifikáns különbség nincsen. Mindebböl kifolyólag a tanulmányban egyáltalán nem teszek különbséget vállalkozások, szervezetek, gazdálkodó szervezetek között, e fogalmakat e munka keretei között szinonimaként használom. Hasonlóképpen nem teszek különbséget a szervezet vezetöi között sem, hiszen a tanulmány szempontjából a determináns jellemvonás, miszerint a szervezeti hierarchia csúcsán elhelyezkedő, irányítási, felügyeleti, valamint ellenőrzési kompetenciával bíró személyről van szó, aki a szervezet tekintetében döntési kompetenciával rendelkezik, valamennyi szervezet vezetője, vezető tisztségviselője vonatkozásában fennáll. A szervezet integritásáért alapvetően a szervezet vezetője felelős (Hießner, 2014). Így van ez akkor is, ha a szervezet vezetője az integritási feladatok ellátását másra delegálja, hiszen a szervezet vezetőjét az integritási feladatok teljesítése vonatkozásában ,átruházhatatlan személyi felelösség” terheli (Dargay, 2015).

\section{A szervezeti integritás és a compliance viszonya}

\section{A compliance jelentése}

A compliance általános jogi értelemben az érvényes és hatályos jognak megfelelöen, azzal összhangban való cselekvést jelenti (Rotsch, 2015). Az angol eredetủ compliance terminus szó szerinti jelentése betartás, egyetértés, követés (Ambrus, 2019; Jacsó, 2019a). A fogalom eredetileg az orvostudományból származik, ahol is a beteg terápiakövetö magatartását jelenti. A jogi fogalomkészletbe való átvételére az orvostudományban használatos fogalomra vont analógiával került sor, mégpedig ,, to be compliance with the law” értelemben. Ennek megfelelően alapvetően az érvényes és hatályos jogi normákkal egyetértésben való cselekvést jelenti. A compliance definíciószerüen mindazon intézkedések összessége, amelyek megtételét megköveteljük a vállalkozásoktól annak érdekében, hogy garantáljuk: a vállalkozások, illetőleg azok tagjai és dolgozói minden jogi norma által elöírt kötelezettséget teljesítsenek, a tilalmakra vonatkozó szabályokat pedig betartsák (Reichert, 2011). A fogalmat szükíteni szükséges azonban azzal, hogy jogi értelemben tipikusan a vállalkozások, jogi személyek, gazdálkodó szervezetek relációjában használatos, e szervezetek 
tagjai általi jogkövető, normakövető magatartást érjük alatta. Szervezeti értelemben azonban nem pusztán valamiféle jogkövető magatartást értünk e fogalom alatt, hanem olyan intézkedések foganatosítását, eszközök létrehozását, amelyek a szervezeten belüli normakövető magatartást garantálni, kikényszeríteni képesek (Bock, 2009). Azaz a compliance egyfajta szervezeten belüli normakonformitás.

A criminal compliance a szervezeti normakövetés büntetőjogi aspektusa. Tárgyát tekintve a büntetőjogilag releváns magatartások elkövetésétől való viszszatartást célzó rendelkezések összessége, valamint e tényállások megvalósításának elkerülését célzó szervezeti intézkedések halmaza (Ambrus \& Farkas, 2019; Jacsó, 2019a). Technikai értelemben tehát a vállalkozások vonatkozásában releváns olyan, tipikusan preventív biztonsági intézkedések gyüjtőfogalma, amelyek célja a szervezeten belül a büntetőjogilag releváns magatartások előfordulása kockázatának, rizikójának csökkentése, eliminálása, a szervezet tagjainak, dolgozóinak jogkövető magatartásra történő rábírás által. A jogkövető magatartásra, szabálykonformitásra történő rábírás eszköze normatív compliance-értelemben a büntetőjogi szankciók, illetve egyéb represszív eszközök kilátásba helyezése is (Rotsch, 2015). A criminal compliance elsődleges célja a bünmegelőzés, azaz szervezeten belül büncselekmények elkövetésének megakadályozása. A represszió általi prevenció a büncselekmény megvalósítására adandó állami válaszreakció okán tipikus criminal compliance eszköznek tekinthetö.

\section{Az integritás és a compliance közötti koncepcionális kapcsolat}

A jog és a morál közötti tartalmi különbség az, hogy nem minden jogi norma nyugszik morális meggyőződésen. A legtöbb jogi norma azonban morális megfontoláson alapul. Így az is igaz, hogy nem minden morális meggyőződés manifesztálódik jogi normaként. A jogi normák betartása abban az esetben is morális elvárássá alakul ugyanakkor, ha maga a norma nem morális megfontoláson alapul (Schöttl, 2017). A pozitív jog ezáltal képes arra, hogy erkölcsileg el nem ítélhető magatartások be nem tartását is mintegy a morális minimum szintjére emelje.

Szervezetekre vonatkoztatva mindez azt jelenti, hogy a compliance, azaz a normák betartása és betartatása a szervezeti integritás feltétele. Főszabály szerint tehát akkor integritás alapú egy szervezet, ha hatékonyan müködő compliance rendszerrel rendelkezik. Lisa Schöttl, szervezeti integritással foglalkozó munkájában hoz példát arra a ritka kivételre, amikor a compliance egyúttal nem 
integritás alapú magatartás. Eszerint előfordulhat, hogy a szervezet, illetve annak tagja, dolgozója olyan norma betartására kötelezett, amely az adott szervezet alapvető gazdasági érdekeit sértő magatartás kifejtését írja elő. E norma be nem tartása compliance-sértő magatartás lehet, egyúttal azonban a szervezeti integritás védelmét szolgálja (Schöttl, 2017). A compliance tehát egyrészről az integritás alapú szervezet megteremtésének eszköz- és fogalomkészlete, ám az integritásnak csupán részeleme. Az integritás nem lenne megvalósítható azonban puszta normakonformitás útján. A compliance alapvetően normaorientált fogalom, amíg az integritás e terminust is átfogó, ám sokkal inkább a morálra koncentráló megközelítés. A két fogalom tehát különbözik, ám egyúttal át is fedi egymást. A különbség sokkal inkább a célmeghatározásukban, mintsem a tartalmukban érhető tetten: a compliance elsődleges célja jogellenes magatartások megakadályozása, megelőzése, az integritás pedig morálisan elvárt, támogatott magatartások tanúsítását mozdítja elő (Schöttl, 2017).

Az integritástudomány egy része különbséget tesz úgynevezett kemény integritáskontroll, valamint lágy integritáskontroll között. Kemény integritáskontroll mindazon rendelkezés, valamint ezek betartását szolgáló eszközrendszer, amely konkrét normák, jogszabályok útján kerül rögzítésre (Boros, 2019; Pulay, 2014; Schöttl, 2017), és tipikusan kívülről jövő kötelezettségként jelenik meg, akkor is, ha a norma betartását szolgáló részletszabályokat maga a szervezet dolgozza ki. A fentiek alapján láthatjuk, hogy az integritástudomány voltaképpen a compliance rendelkezéseket tekinti kemény normatív integritáskontrollnak. E tekintetben tehát tág értelemben vett integritáskontrollról beszélhetünk. Ezzel szemben lágy integritáskontrollról beszélünk akkor, ha a szervezet olyan magatartási szabályokat határoz meg, amelyek jogi normában nincsenek rögzítve, azonban meghatározott elvek és értékek követésére ösztönzik a szervezet tagjait, dolgozóit. Ezt tekinthetjük szük értelemben vett integritáskontrollnak (Boros, 2019; Pulay, 2014). Boros Anita a következőképpen ragadja meg a compliance, valamint az integritás közötti viszonyrendszert: „, a szükebb értelemben vett integritási eszközök azt a célt szolgálják, hogy a szervezet tagjai ne csak kövessék az elöirásokat, hanem azonosulni is tudjanak azok mögöttes tartalmával, célrendszerével, értékeivel és ezt ne csak akkor tegyék, ha ellenörzik és szankcionálják öket” (Boros, 2019). Amíg tehát a compliance a jogra koncentrál, addig az integritás az erkölcsre, a morálra. A compliance-szemlélet célja a jogi normák betartatása (criminal compliance esetén büncselekményi tényállás megvalósításától való visszatartás), az integritásszemlélet célja pedig olyan szervezeti atmoszféra létrehozása, amelyben a szervezet tagjai, dolgozói olyan elvek mentén léteznek és múködnek (Schöttl, 2017), amelyek őket a viszszaélések elkövetésétől való tartózkodásra kondicionálják. Látható tehát, hogy 
aki jogi normáknak megfelelően viselkedik (compliant with law), az szolgálja a szervezeti integritást, ugyanakkor a normáknak való megfelelés a szervezeti integritás megteremtéséhez nem elegendő. Ha compliance szemszögből nézzük az integritási eszközöket, a kettő közötti kapcsolat oly módon ragadható meg, hogy az integritási szemlélet célja a compliance hatékonyságának növelése, javítása, optimalizálása.

Ahogyan láthattuk, az integritás, valamint a compliance közötti különbség azok tárgyának rész-egész halmazban történő értelmezése mellett a szemléletmódjukban ragadható meg. Amíg a compliance-szemléletet a normativitásra koncentrálva az ,, azt tesszük, amit kell, mert ezt kell tenni” hozzáállás jellemzi, addig az integritásszemlélet esetén sokkal inkább dominál az „,akarom azt tenni, amit tenni kell " hozzáállás (Schöttl, 2017). A compliance célorientált és a szankció dominál, amíg az integritás értékorientált és a motivációt helyezi az előtérbe.

\section{A szervezeten belüli visszaélések elkövetésének fokozott kockázatát megalapozó tényezők}

\section{A szervezeti bünözés jelentése és típusai}

A természetes személyek saját magatartásukat morális elveknek megfelelően fejtik ki, motívumok harca dönt arról, hogy az általánosan elismert morális vezérfonalakat erősebb motívum felülírja-e. Alapvetően ezek az általános, társadalom által elismert és követett morális mércék teszik lehetővé azt, hogy az emberek egymás mellett képesek legyenek élni. Amennyiben a morális mércéken alapuló normákat az egyén megsérti, úgy tipikusan negatív jogkövetkezményével kell szembenéznie (Renz, Frischherz \& Wettstein, 2015). A szervezetek olyan entitások, amelyek egyrészt személyek összessége, ugyanakkor azok múködésében és célmeghatározásában nem az egyének individuuma dominál, hanem konkrétan meghatározható, az egyes egyének individuumától elváló sui generis szervezeti érdek. A szervezet tehát egy olyan kollektív szereplö, amely saját, a tagjai személyétől elváló identitással rendelkezik (Schöttl, 2017). A szervezet részét képező személyek a szervezeti céloknak és érdekeknek megfelelően kell, hogy tevékenységüket végezzék. Nem lehet azonban figyelmen kívül hagyni azt, hogy a szervezeti célok elérése individuumokon keresztül történik, akiknek egyéni céljaik és érdekeik is vannak, amelyek nem ritkán nem egyeznek meg a szervezeti érdekkel, mégis a vállalkozás optimális müködése érdekében a szervezeti érdekeket sértö individuális érdekeket e tekintetben a kollektív érdek érvényesülésének szem előtt tartásával háttérbe kell szorítani. Amennyiben 
a szervezet érdekében kerül sor olyan büncselekmény elkövetésére, amelynek megvalósítását a szervezeti struktúra támogatta, de legalábbis annak vezetője a magatartás felett szemet hunyt, úgy szervezeti bünözésről beszélhetünk. Inzelt és Bezsenyi definíciója alapján a szervezeti bünözés azon jogellenes cselekményeket foglalja magában, amelyeket egy cég alkalmazottai követnek el a cég, valamint a saját érdekeinek előremozdítása érdekében (Inzelt \& Bezsenyi, 2021). A szervezeten belüli visszaélések elkövetésének fokozott kockázata nem elsősorban a cselekmény súlyosságában, az államot, avagy természetes személyt károsító voltában ragadható meg, hanem e cselekmény rejtve maradásának nagy esélye okozza az elsődleges problémát. A szervezeteket jellemző zárt, hierarchikus struktúra alkalmas környezetet biztosít a büncselekmények elkövetésének leplezéséhez, azaz a szervezeten belüli kriminális tevékenység jelentős része marad látens, rejtett a bünüldöző hatóságok előtt. A szervezetek e tulajdonsága pedig motivációs tényezőként hathat olyan büncselekmények elkövetése tekintetében, amely közvetlenül vagy közvetve szervezeti érdeket szolgál. Ahogyan Eidam Lutz megfogalmazza, a komplikált szervezeti struktúra, a jellemzően munkamegosztáson alapuló munkavégzés nemcsak magasfokú látenciához vezet, hanem képes optimális környezetet teremteni az individuális büntetőjogi felelősség elkendőzéséhez (Eidam, 2015), azaz még ha bizonyított is, hogy büncselekmény elkövetésére került sor a szervezeten belül (azaz maga a cselekmény a hatóság tudomására jut), gyakorta szinte lehetetlen annak megállapításra, hogy a felelősség mely természetes személyt terheli.

Amennyiben a szervezeten belül büncselekmény elkövetésére kerül sor, nem törvényszerü, hogy annak leplezése szervezeti érdekként jelenik meg. E jelenség veszélye abban az esetben fokozott, amennyiben a büntetőjogilag releváns visszaélés szervezeti érdeket szolgál. A szervezeten belüli bünözéssel foglalkozó német kriminológiai, valamint criminal compliance szakirodalom két csoportra osztja a szervezeten belüli bünelkövetések körét attól függően, hogy szervezetet terhelö (Belastungskriminalität), vagy a szervezet javát szolgáló bünelkövetésről (Entlastungskriminalität) van-e szó (Bock, 2011; Rotsch, 2015). A szervezet javát szolgáló bünelkövetés esetén a vállalkozás érdekében álló olyan, büntetőjogilag releváns magatartásokról van szó, amelyek tipikusan a szervezetből kifelé irányulnak, a vállalkozás részére előnyszerzést céloznak, a szervezeten kívül álló személyek, illetve más szervezetek ellen irányulnak, azoknak potenciálisan hátrányt okoznak. Szervezetet terhelö bünelkövetés ezzel szemben az, amikor a vállalkozás tagja vagy dolgozója a büntetőjogilag releváns cselekményt nem a szervezet érdekében vagy annak javára követi el, hanem célja, avagy cselekményének következménye a szervezetnek történő hátrányokozás (Rotsch, 2015), illetve saját magának vagy másnak történő előnyszerzés. A két fogalom mentén történő csoportképzés 
relatív, érdekelemzés eredményétől függ, hogy adott büncselekmény a szervezet érdekében, avagy azzal szemben került elkövetésre (Bock, 2011).

Bủnmegelőzési szempontból e differenciálás alapján megállapítható, hogy amíg a szervezet ellen irányuló büncselekmények ellen fellépni közvetlen szervezeti érdek (így például a szervezeti hajlandóság magas olyan antikorrupciós intézkedések megtételére, amelyek az ellene irányuló magatartások kiszürését célozzák), addig a szervezet érdekében álló büncselekmények esetén az érdekharmónia a javakból részesülő szervezet és a büncselekmény elkövetője között áll fenn. Amíg az első esetben a bünmegelőzés, valamint a bünfelderítés az állam és a szervezet közös érdeke, addig az utóbbi esetben az állam és a szervezet között érdekkollízió áll fenn, ugyanis a szervezet érdeke a törvényes müködés látszatának fenntartása, az érdekét szolgáló büncselekmény látenciája (Bock, 2011). Éppen ezen érdekkollízió miatt szükséges a szervezet érdekében elkövetett deliktumok esetén a fokozottabb állami fellépés mind a bünmegelőzés, mind pedig a bünfelderítés terén (Hellmann \& Beckemper, 2013).

\section{Szervezeten belüli büncselekmények elkövetésének motivációs rendszere}

Irk Ferenc széles körü krimináletiológiai vizsgálatot végzett, és elméletek mentén vázolja fel tanulmányában, hogy alapvetően milyen tényezők és döntési folyamatok vezetnek a szervezeten belüli büncselekmények elkövetéséhez (Irk, 2014). E folyamat megértése profilaktikai szempontból azért elkerülhetetlen, mert az ismert motivációs tényezők kiküszöbölése jelenti a bünmegelőzési relevanciával bíró integritási eszközöket és intézkedéseket. Az egyéni döntéseket általánosságban nemcsak az individuális motivációk determinálják, hanem a makroszinten megjelenő, azaz a társadalmi motívumok is meghatározzák. A szervezeti bünelkövetés esetén még speciálisabb a helyzet, hiszen mezoszinten jelen van maga a szervezet is, amely saját identitása kollízióba kerülhet mind az individuummal, mind pedig a társadalmi normákkal. A szervezet társadalmi normákkal való szembehelyezkedése, illetve annak kriminális konzekvenciái nem képezik e tanulmány tárgyát, integritási szempontból kevéssé relevánsak. Sokkal fontosabb e tekintetben annak a kérdésnek a vizsgálata, hogy a szervezet és az individuum milyen motivációk mentén kerül egymással olyan kölcsönhatásba, amely az egyént szervezeti érdeket szolgáló büncselekmény elkövetésére ösztönözheti.

Az egyéni döntéshozatali metodika folyamatában alapvetően a szabad akarat dominál, azaz főszabály szerint mindenki eldöntheti, hogy követ-e el 
büncselekményt vagy sem. Amennyiben a büncselekmény elkövetésére történő befolyásolás eléri azt a mértéket, amelyet a befolyásoló tekintetében a büntetőjog is szankcionál, úgy ez a döntési szabadság erőteljesen relativizálódik, adott esetben meg is szünik. Az egyén által hozott döntések azonban akkor sem teljes mértékben indetermináltak, ha explicit befolyásolásról in concreto nincsen szó. Az egyén ugyanis döntéseinek meghozatala során szükségképpen hatása alatt áll környezete értékrendjének, a mikro-, mezo-, valamint makrokörnyezeti hatások nehezen küszöbölhetők ki. Az egyén által hozott döntések bizonyos szinten tehát azon környezet által determináltak, amelynek az egyén a része (Irk, 2014). Ahogyan Irk szervezeti szempontból megfogalmazza: ,, $a z$ egyént a vállalaton belül az a szemlélet hatja át, amely a vállalat egészét" (Irk, 2014). A racionális döntés elméletének szervezetre történő specializálása azt jelenti, hogy abban az esetben, ha a szervezet érdekében realizált büntetőjogilag releváns magatartások elkövetése a szervezeti kultúra szintjén nem jelenik meg negatív tényezőként, sőt e cselekmények felett a vezetők rendre szemet hunynak, úgy racionális döntés olyan jogellenes magatartás kifejtése is, amely a szervezet érdekében (is) történik, hiszen a vállalkozás megvéd a leleplezödéstöl. A szervezet eredményességének elérése ilyenkor könnyen a szervezetre vonatkozó külső szabályok betartása elé helyeződhet. Az egyén tudva azt, hogy a szervezet vezetöi a siker érdekében szemet hunynak a kisebb normasértések felett, motiválttá válik azok elkövetésére (Irk, 2014). Ez esetben tehát a szervezeti kultúrát nemhogy nem hatja át a szervezet érdekében történő viszszaélésszerü magatartásoktól való tartózkodás, hanem éppen ellenkező előjelü szellemiség a jellemző, amely környezetben az egyén - individuális motivációjának megléte esetén - aligha válik motiválttá a büncselekmény elkövetésétől való tartózkodásra. A szervezet müködésének törvénysértő voltát in abstracto megállapíthatóvá teszi, hogy az lehetőséget biztosít arra, avagy eltüri azt, hogy a javára vagy érdekében realizált, büntetőjogi szempontból is releváns cselekmények a keretei között megvalósuljanak.

Ha a szervezet érdekében kifejtett magatartás vonatkozásában a szervezet nem fejezi ki rosszallását, úgy a feltétlen reflexió elmaradása önmagában motiváló tényezőként hat további magatartások kifejtése tekintetében. Amennyiben a szervezet tagja a szervezet érdekében követ el büncselekményt, könnyen semlegesítheti magában a negatív erkölcsi vonzatot azzal, hogy a nagyobb jó érdekében cselekedett. A nagyobb jó ebben az esetben - potenciális saját érdekei mellett - a szervezet érdeke. Ezt a jelenséget hívja a kriminológia neutralizálásnak (Irk, 2014). A neutralizálás mellett pedig a cselekménnyel szembeni általános erkölcsi rosszallás is marginalizálódik az egyénben, így az adott magatartás kifejtése tekintetében többé nincsen szubjektív visszatartó erő. Éppen ezért nagyon fontos 
az, hogy a szervezeti kultúrát egyértelmüen áthassa a korrupciós, és egyéb, büntetőjogilag releváns magatartások elutasítása mint szemlélet, csak ezáltal érhető el, hogy a szervezet tagja, dolgozója az adott büncselekmény elkövetésétől való tartózkodásban váljon érdekeltté. Ezért elengedhetetlen a feltétlen reflexió a legapróbb szervezeti normasértés esetén is. Fontos hozzátenni, hogy önmagában a szankcióval való fenyegetésnek nincsen elrettentő hatása, tehát egy krudélis büntetési tétel sem tartja vissza a büncselekmény elkövetöjét a magatartás kifejtésétöl akkor, ha arra van lehetösége, valamint akkor, ha a cselekmény felderítésének veszélye, és ezáltal a vele szemben alkalmazandó szankció kiszabásának esélye minimális, de legalábbis sokkal alacsonyabb, mint az elkövetett büncselekménnyel járó nyereség. Ebben az esetben racionális döntés lehet a kockázatvállalás, ezáltal a szankcióval való fenyegetés nem hat negatív ösztönző tényezőként.

\section{Integritásmenedzsment a büntetőjogi felelősség megelőzése érdekében}

A szervezet feladata a vállalkozás szabályszerü, egységes, integritás alapú müködésének megteremtése, olyan etikus vezérelvek és belső normák kidolgozásán keresztül, amelyek meghatározzák azt a keretrendszert, amelyben az individuumok a tevékenységüket végezni kötelesek és jogosultak. Amennyiben koherens és jól működő rendszert épít ki a szervezet, úgy elkerülheti azt, hogy keretei között büncselekmény kerüljön elkövetésre, ezáltal pedig azt, hogy büntetőjogi felelősségre vonásra kerüljön sor. A jól működő integritásmenedzsment-rendszer felépítéséhez elengedhetetlenek az olyan pozitív tényezők, amelyek integer és compliant magatartásra (etikus és jogkövető viselkedésre) motiválják a szervezet tagjait, dolgozóit. Melcher ismertet Frederick Herzberg kéttényezős motivációs elméletéhez hasonló logikai felépítést a szervezeten belüli integritás alapú magatartáskifejtésre motiváló tényezők tekintetében. Herzberg kéttényezős motivációs elméletében a higiéniai tényezők azok, amelyek elégedettséget nem okoznak, csak az elégedetlenség szüntethető meg velük, ezért azok motivációra nem alkalmasak. A motivátorok hiánya nem okoz elégedetlenséget, csak az elégedettség hiányát, az embereket a motivációs tényezők teszik elégedetté. Ez a megállapítás igaz a szervezeti integritást elősegítő tényezők vonatkozásában is: a negatív elemek megszüntetése önmagában nem okoz etikai szempontból előrelépést, viszont meglétük az etikus kultúrára negatív hatással van. Ezzel szemben a pozitív elemek létezése előmozdítja az etikus szervezeti kultúra kiépítését (Melcher, 2019). Ezért ösztönző tényezőként előtérbe kell helyezni a pozitív motivációs elemeket. 


\section{Az integritásmenedzsment jelentése}

Egy szervezet akkor integritás alapú, ha rendszeresen felismeri azokat a területeket, ahol etikai-morális feszültségek jelentkezhetnek, ezeket a területeket és potenciális konfliktusforrásokat analizálja, majd azokat meg is oldja (Renz, Frischherz \& Wettstein, 2015). Az integritásmenedzsment célja az, hogy olyan tényezőket rögzítsen a szervezeti struktúrában, amelyek a szervezet tagjait szabályszerü és integritás alapú magatartás tanúsítására ösztönzik (Schöttl, 2017). A szervezeti integritásmenedzsment három fó pillére tehát a kockázatfelismerés, kockázatelemzés és a problémamegoldás. Dargay a következőképpen foglalja össze az integritásszemlélet föbb elemeit: szervezeti szinten nagyon fontos a kockázatelemzés, amely tipikusan a múltban bekövetkezett események alapján hivatott felmérni azokat a kockázati tényezőket, amelyek tekintetében indokolt konkrét szabályrendszer, valamint annak betartatására hivatott eszközrendszer kiépítése. Ahogyan fentebb láttuk, az integritásszemlélet nem csak a makro-, valamint a mezoszintre kell, hogy koncentráljon, nem hagyható figyelmen kívül az, hogy a szervezet müködését individuumok befolyásolják. Ezért az integritásszemlélet fontos eleme a mikroszintre, az egyéni szintre történő figyelemfordítás is: a szervezetben dolgozók integritását is erősíteni kell (Dargay, 2015).

\section{Felelősségelkerülést célzó integritási eszközrendszer}

A felelősségelkerülés integritási értelemben azt jelenti, hogy a szervezet megtesz minden olyan intézkedést, amely azt a célt szolgálja, hogy a vállalkozás érdekében, illetve annak felhasználásával a tagok, dolgozók ne kövessenek el büncselekményt, ezáltal az individuumok jogszerü magatartásra ösztönzésével kerülik el a szervezet felelősségre vonását. Tekintettel arra, hogy az integritás és a compliance fogalmának egymáshoz való viszonyából kifolyólag a compliance eszközök egyúttal integritási eszközök is, e fejezet nem szorítkozik a tisztán etikai, morális elvek követését elősegítő eszközök exemplifikatív felvázolására, hanem azon eszközökre fókuszál, amelyek a büntetőjogilag releváns magatartások kifejtésétől tartja vissza a szervezet tagjait, dolgozóit. Ennek az az oka, hogy a büntetöjogi felelősség szempontjából releváns rendelkezések szervezeti szempontból mindig compliance rendelkezések, hiszen a büncselekményi tényállások és diszpozíciók realizálásától való tartózkodásban áll a szabálykövetés. A compliance-menedzsment Heißner megfogalmazása szerint nem más, mint szisztematikus kísérlet arra, hogy a szervezet vezetôi a szervezetet érintő jogi előírásokat átültessék a szervezeti kultúrába annak érdekében, hogy a károkozás, 
illetve egyéb visszaélés esetén bekövetkezö felelősségüket kizárják (Heißner, 2014). A tanulmánynak nem célja egy optimális compliance eszközrendszer részletes és teljes körú ismertetése, kifejezetten azokra a rendelkezésekre fókuszál, amelyek a büncselekmények megvalósításától való tartózkodást célozzák. Az optimális compliance eszközrendszer kiépítéséhez vezető első lépcső a kockázatfeltárás, kockázatelemzés, azaz a rizikómenedzsment. Általános compliance kockázatot jelent valamennyi szervezetre a rájuk vonatkozó külső, valamint belső szabályozók rendelkezéseinek be nem tartása. Általános, nem szervezetspecifikus kockázatnak tekinthető például a titokkockázat, a reputációvesztés kockázata, a korrupciós kockázat, az adóelkerülési kockázat, a pénzmosási kockázat, a fogyasztóvédelmi kockázat, valamint a versenyjogi kockázat. Jacsó Judit a compliance-releváns kockázatokat négy csoportba sorolja: jogi kockázatok, felügyeleti vagy egyéb hatósági szankciók kockázata, pénzügyi veszteség, hírnévvesztés kockázata (Jacsó, 2019b).

A compliance-menedzsment rendszer normatív, intézményi, valamint technikai jellegü eszközökből áll. Az alábbiakban mindhárom eszköztípusra egy-egy olyan példát hozok, amely criminal compliance szempontból is jelentős kriminálpreventív eszköz. Kifejezetten integritásszemléletủ compliance intézkedésnek tekinthető a szervezeten belül etikai kódex létrehozása, valamint a szervezet tagjainak és dolgozóinak rendszeres képzése, oktatása, amely a szervezet által elvárt viselkedési morál rögzítését és megerősítését szolgálja. Az etikai kódex által meghatározott magatartási szabályok között indokolt a szervezetreleváns büncselekményekre, illetve az azok megvalósításától való tartózkodásra is felhívni a figyelmet, hiszen egy szervezet által rendelkezésre bocsátott kódex sokkal közvetlenebbül szolgálja az elvárt szervezeti kultúra megvalósulását, mint a külső normatív szabályok. Intézményi jellegű compliance eszköz az úgynevezett compliance officer pozíció integrálása a szervezetrendszerbe, amely személy elválasztása a szervezet vezetőjének személyétől azt a célt szolgálja, hogy minél inkább koncentráltan jelenhessen meg a szervezeten belül az integritási tevékenységek végzése. Criminal compliance szempontból azért üdvözlendő, mert a büntetőjogilag releváns visszaélések, valamint annak majdani megvalósulására utaló gyanújelek felismerése nem ritkán különös szakértelmet igényel, ezért optimális, ha e célra önálló pozíció létesül. Technikai jellegủ compliance eszköz például szervezeten belüli whistleblower-hotline, más néven visszaélésbejelentési rendszer kiépítése és üzemeltetése. Abban az esetben, ha a szervezeten belül normasértés következik be, úgy individuális és szervezeti érdek is egyúttal, hogy garantálva legyen az, hogy azokat a szervezet tagjai anonim módon tudják jelenteni a szervezet vezetőjének, illetve az e feleadatra rendelt személynek. A visszaélésbejelentési rendszer criminal compliance szempontból 
elsősorban bünfelderítési eszközként jön szóba, azonban a represszió általi prevenció tétele itt is érvényesül azáltal, hogy ha a rendszer optimálisan müködik, úgy az visszaélések elkövetésétől történő visszatartó erőként jelenik meg, ezáltal hatásában kriminálprevenciót is szolgál (whistleblowing témában lásd részletesen: Ambrus \& Farkas, 2019; Heißner, 2014; Molnár, 2016).

\section{Összegzés}

A szervezet integritás alapú müködése, azaz morális elveknek, valamint jogi normáknak történő megfelelése a bủnmegelőzés hatékony eszköze. Indokolt ezért az integritáselméletet és integritástudományt a kriminológia részterületeként, a kriminálprofilaxis kutatási területeként is kezelni. A szervezetek elemi érdeke az, hogy annak keretei között ne kerüljön elkövetésre büncselekmény. Egyértelmü az, hogy valamennyi szervezet intézkedéseket foganatosít a vele szemben kifejtett jogellenes magatartások megakadályozása érdekében, nem ennyire zsigeri reakció ugyanakkor védelmi mechanizmusok és intézményrendszer kiépítése abban az esetben, ha a büncselekmény elkövetése szervezeti érdeket (is) szolgál. Nem ritka, hogy ilyen esetben a szervezet érdeke az, hogy az ilyen magatartások megvalósulását a külvilág előtt leplezze. E tekintetben nyújt motivációs eszközöket az integritás, valamint a compliance szemlélet. A szervezet érdekében elkövetett büncselekmények kapcsán maga a szervezet is felelősséggel tartozhat, így motiválttá válik abban is, hogy a financiális érdekét szolgáló büncselekmények elkövetését se tolerálja. Az integritásmenedzsment ezáltal a kriminálprofilaxis elöremutató instrumentumának tekinthető.

\section{Felhasznált irodalom}

Ambrus I. \& Farkas Á. (2019). A compliance alapkérdései. Az etikus vállalati müködés elmélete és gyakorlata. Wolters Kluwer.

Bock, D. (2009). Strafrechtliche Aspekte der Compliance-Diskussion - 130 OWiG als zentrale Norm der Criminal Compliance. Zeitschrift für Internationale Strafrechtsdogmatik, (2), 68-81.

Bock, D. (2011). Criminal Compliance. Nomos. https://doi.org/10.5771/9783845230412

Boros A. (2019). Az állami ellenőrzés egy sajátos válfaja, avagy a megfelelőség (compliance) és az integritás kérdésköre egyes közszféraszervezetek esetében. Magyar Közigazgatás, (2), 4-27. https://doi.org/10.32575/ppb.2019.2.1

Dargay E. (2015). Integritás, mint a korrupciómegelőzés eszköze a közigazgatásban. Polgári Szemle, 11(4-6), 361-371. 
Eidam, L. (2015). Der Organisationsgedanke im Strafrecht. Mohr Siebeck. https://doi. org/10.1628/978-3-16-153820-9

Hellmann, U. \& Beckemper, K. (2013). Wirtschaftsstrafrecht. 4., neu bearbeitetet Auflage. Kohlhammer.

Hießner, S. (2014). Erfolgsfaktor Integrität. Wirtschaftskriminalität und Korruption erkennen, aufkläre, verhindern. Springer Gabler. https://doi.org/10.1007/978-3-658-01137-6_4

Inzelt É. \& Bezsenyi T. (2021). A vállalati bünözés jellemzőinek megértése: elméleti megfontolások és empirikus kutatás eredményei alapján. ELTE Eötvös Kiadó.

Irk F. (2014). A kockázattársadalom menedzserdevianciáiról. Kriminológiai Tanulmányok, 51, 9-25. Jacsó J. (2019a). A compliance fogalmáról és szerepéről a gazdasági életben. Miskolci Jogi Szemle, 14(1Klnsz), 82-91.

Jacsó J. (2019b) A pénzmosás compliance hazai és európai dimenzióban a társadalmi innováció tükrében. Miskolci Jogi Szemle, 14(2/1), 394-412.

Klotz P. (2017). Integritás ante portas. Magyar Rendészet, 17(1), 91-102.

Melcher I. (2019). A szervezeti integritás és az etikus gazdálkodás ellenőrzése közszolgáltató szervezeteknél. Észak-magyarországi Stratégiai Füzetek, 16(3), 37-51. https://doi.org/10.32976/ stratfuz.2019.4

Molnár E. (2016). A közérdekű bejelentés bűnmegelőzési és bűnfelderítési relevanciájának vizsgálata a gazdálkodó szervezeten belül elkövetett büncselekmények vonatkozásában. Belügyi Szemle, 64(9), 76-100. https://doi.org/10.38146/BSZ.2016.9.5

Molnár E. (2021). A szervezeten belüli elönyomozási eljárás alkalmazásának lehetöségei az államigazgatási szervek körében. Dialog Campus.

Pulay Gy. (2014). A korrupció megelőzése a szervezeti integritás megelőzése által. Pénzügyi Szemle, 59(2), 151-166.

Reichert, J. (2011). Reaktion pflichten und Reaktionsmöglichkeiten der Organe auf (möglicherweise) strafrechtsrelevantes Verhalten innerhalb des Unternehmens, Zeitschrift für Internationale Strafrechtsdogmatik, (3), 113-122.

Renz, P. S., Frischherz, B. \& Wettstein, I. (2015). Integrität im Managementalltag. Ethische Dilemmas im Managementalltag erfassen und lösen. Springer Gabler. https://doi.org/10.1007/9783-662-44418-4

Rotsch, T. (2015). Grundlagen. Criminal Compliance - Begriff, Entwicklung, theoretische Grundlegung. In Rotsch, T. (Ed.), Criminal Compliance (pp. 31-81). Nomos.

Sántha F. (2002). A jogi személy büntetőjogi felelösségéröl. KJK-Kerszöv.

Schöttl, L. (2017). Integrität in Unternehmen. Konzept, Management, Maßnahmen. Springer Gabler. megelőzése érdekében - Integritáselmélet kriminálprofilaktikus megközelítésben 


\section{Alkalmazott jogszabályok}

50/2013. (II. 25.) Korm. rendelet az államigazgatási szervek integritásirányítási rendszeréről és az érdekérvényesítők fogadásának rendjéről

370/2011. (XII. 31.) Korm. rendelet a költségvetési szervek belső kontrollrendszeréről és belső ellenőrzéséről

1994. évi XXXIV. törvény a Rendőrségröl

2020. évi CLXII. törvény a Kormányzati Személyügyi Döntéstámogató Rendszerről

\section{A cikk APA szabály szerinti hivatkozása}

Molnár E. (2021). Szervezeti integritás a büntetőjogi felelősségre vonás megelőzése érdekében

- Integritáselmélet kriminálprofilaktikus megközelítésben. Belügyi Szemle, 69(11), 1943-1961. https://doi.org/10.38146/BSZ.2021.11.4 